\title{
Holocene paleoenvironmental records from Nikolay Lake, Lena River Delta, Arctic Russia
}

\author{
Andrei Andreev ${ }^{\mathrm{a}, *}$, Pavel Tarasov ${ }^{\mathrm{b}}$, Georg Schwamborn ${ }^{\mathrm{a}}$, Boris Ilyashuk ${ }^{\mathrm{c}}$, \\ Elena Ilyashuk ${ }^{\mathrm{c}}$, Anatoly Bobrov ${ }^{\mathrm{d}}$, Vladimir Klimanov ${ }^{\mathrm{e}}$, \\ Volker Rachold $^{\mathrm{a}}$, Hans-Wolfgang Hubberten ${ }^{\mathrm{a}}$ \\ ${ }^{a}$ Alfred-Wegener-Institut für Polar-und Meeresforschung, Forschungsstelle Potsdam, Telegrafenberg A43, D-14473 Potsdam, Germany \\ ${ }^{\mathrm{b}}$ Department of Geography, Moscow State University, Vorobievy Gory, 119899 Moscow, Russia \\ ${ }^{\mathrm{c}}$ Institute of North Industrial Ecology Problems, Kola Science Center, Russian Academy of Sciences, Fersman St. 14, 184200 Apatity, Russia \\ ${ }^{\mathrm{d}}$ Department of Soil Sciences, Moscow State University, Vorobievy Gory, 119899 Moscow, Russia \\ ${ }^{\mathrm{e}}$ Institute of Geography, Russian Academy of Sciences, Staromonetny 29, 109017 Moscow, Russia
}

Received 3 February 2003; accepted 5 February 2004

\begin{abstract}
Radiocarbon-dated pollen, rhizopod, chironomid and total organic carbon (TOC) records from Nikolay Lake $\left(73^{\circ} 20^{\prime} \mathrm{N}\right.$, $124^{\circ} 12^{\prime} \mathrm{E}$ ) and a pollen record from a nearby peat sequence are used for a detailed environmental reconstruction of the Holocene in the Lena Delta area. Shrubby Alnus fruticosa and Betula exilis tundra existed during 10,300-4800 cal. yr BP and gradually disappeared after that time. Climate reconstructions based on the pollen and chironomid records suggest that the climate during ca. 10,300-9200 cal. yr BP was up to $2-3{ }^{\circ} \mathrm{C}$ warmer than the present day. Pollen-based reconstructions show that the climate was relatively warm during 9200-6000 cal. yr BP and rather unstable between ca. 5800-3700 cal. yr BP. Both the qualitative interpretation of pollen data and the results of quantitative reconstruction indicate that climate and vegetation became similar to modern-day conditions after ca. $3600 \mathrm{cal}$. yr BP. The chironomid-based temperature reconstruction suggests a relatively warm period between ca. 2300 and 1400 cal. yr BP, which corresponds to the slightly warmer climate conditions reconstructed from the pollen. Modern chironomid and rhizopod assemblages were established after ca. 1400 cal. yr BP.
\end{abstract} (C) 2004 Elsevier B.V. All rights reserved.

Keywords: Holocene; Lake sediments; Biological records; Climate and vegetation history; East Siberian Arctic

* Corresponding author. Fax: +49-331-2882137.

E-mail addresses: aandreev@awi-postdam.de (A. Andreev), paveltarasov@hotmail.com (P. Tarasov), gschwamborn@awi-postdam.de (G. Schwamborn), ilyashuk@inep.ksc.ru (B. Ilyashuk), elena.ilyashuk@inep.ksc.ru (E. Ilyashuk), Anatoly@bobrov.soils.msu.su (A. Bobrov), paleo@glasnet.ru (V. Klimanov), hubbert@awi-postdam.de (H.-W. Hubberten).

\section{Introduction}

Reconstructing the climate history of high Arctic regions is important for understanding present and past vegetation and climate changes in the Northern Hemisphere. The study of Arctic paleoenvironmental records enables qualitative and quantitative estimations of past climate changes and provides a basis for prediction of future changes in the region. 
Fossil pollen records are a source of information about past changes of vegetation and can be used for quantitative reconstruction of climatic changes. The fossil remains of chironomids (non-biting midges, Diptera: Chironomidae), and rhizopods (testate amoebae, Protozoa: Testaceae) are also increasingly used. Chironomids spend much of their life cycle as aquatic larvae and many species are stenotopic. They respond rapidly to climatic fluctuations because of their short life cycles and the dispersal abilities of the winged adults. Temperature is usually the most important parameter explaining the geographic distribution and abundance of midges (Walker et al., 1991; Brooks and Birks, 2001). The chitinous head capsules, abundant and well preserved in lake sediments, are a valuable source of information for reconstructing paleoenvironmental change (Walker, 2001). Testate amoebae are a group of free-living protozoans with an organic shell (testa). Their welldefined ecological preferences and the relatively good preservation of fossil shells in lake sediments, peats and buried soils make them useful for the reconstruction of climate and environmental changes (Harnisch, 1927, 1948; Grospietsch, 1953; Schönborn, 1962; Meisterfeld, 1977; Tolonen, 1986).

Despite increased research of the Siberian Arctic over the last decades, the paleoenvironments of the
Lena River Delta are still poorly understood. Andreev et al. (2002) examined late Quaternary pollen records from the Bykovsky Peninsula (Laptev Sea coast, location 3 on Fig. 1) east of the delta. The Bykovsky Peninsula Ice Complex deposits accumulated during the last $60,000{ }^{14} \mathrm{C}$ yr BP. Mostly open Poaceae and Cyperaceae associations with Asteraceae, Artemisia, Ranunculaceae, Caryophyllaceae and Cichoriaceae dominated in the area during the late Pleistocene. Unfortunately, the Holocene pollen data from the peninsula are discontinuous because Ice Complex sedimentation stopped ca. 14,000 cal. yr BP. The radiocarbon-dated pollen spectra indicate that shrubby (Betula sect. Nanae, Alnus fruticosa, Salix, Ericales) tundra covered the Bykovsky Peninsula between ca. 9100 and 5200 cal. yr BP. After that time, vegetation and climate became similar to modern (Andreev et al., 2002).

Changes in the diatom (Laing et al., 1999), pollen, stomate (Pisaric et al., 2001a) and midge (Porinchu and Cwynar, 2002) assemblages in a core from a forest-tundra lake south of the Lena River Delta (Fig. 1) location 4 reflect environmental changes since at least ca. 14,000 cal. yr BP. The records clearly show late glacial environmental changes, which can be interpreted as Allerød and Younger Dryas events. The data suggest that the treeline

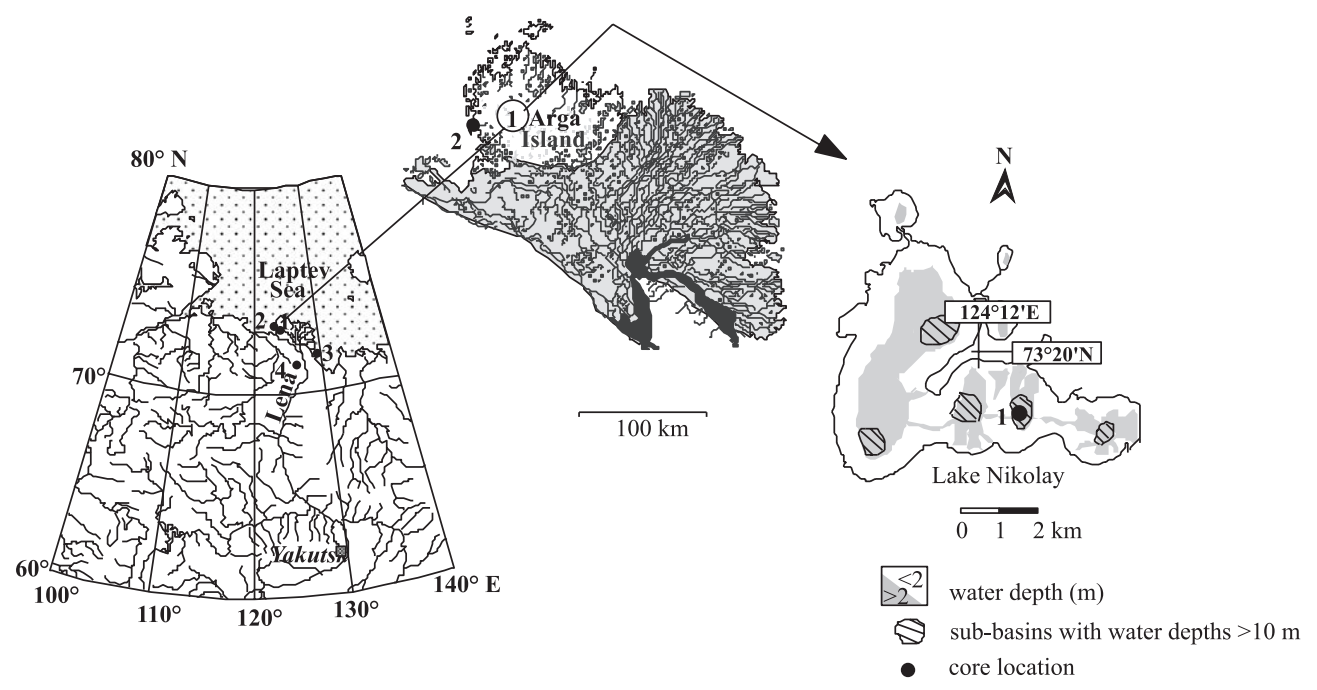

Fig. 1. Maps showing the location of coring sites in the Nikolay Lake (Lena River Delta) and other sites studied in the region. 1-Nikolay Lake core; 2-Barbarina Tumsa section; 3-Bykovsky Peninsula; 4-Dolgoe Lake core. 
advanced across the region from ca. 9100 cal. yr BP and subsequently retreated southwards from ca. 4100 cal. yr BP.

This paper presents a multiproxy investigation of the Holocene climate, vegetation and lake ecosystem dynamics in the western part of the Lena Delta, where relatively little paleoecological work has been carried out to date. The reconstructions are based on the interpretation of pollen, rhizopod, chironomid and total organic carbon (TOC) records from the sediments of Nikolay Lake. The chronology is based on 13 AMS ages. Additionally, an AMS-dated pollen record from a nearby sandy peat sequence is also used for reconstruction of vegetation changes.

Quantitative climate reconstructions using the Nikolay Lake pollen record are performed with the information-statistical (IS) (Klimanov, 1976, 1984) and best modern analogues (BMA) methods (Guiot, 1990). Applying two different approaches provides a more robust reconstruction. Both methods have already been applied to fossil pollen records from northern Eurasia, including sites from the Russian Arctic (e.g., Frenzel et al., 1992; Cheddadi et al., 1997; Velichko et al., 1997; Andreev and Klimanov, 2000; Andreev et al., 2003, 2004). Furthermore, a quantitative reconstruction of mean July air temperature was performed using a chironomid-temperature inference model based on a modern calibration set from a subarctic region of northern Sweden (Larocque et al., 2001).

\section{Study area}

Nikolay Lake $\left(73^{\circ} 20^{\prime} \mathrm{N}, 124^{\circ} 12^{\prime} \mathrm{E}\right)$ is the largest body of water in the Lena River Delta region and is situated in the northwestern part of Arga Island (Fig. 1). The island is one of the major geomorphologic elements of the Lena Delta and is characterised by numerous lakes with a submeridional orientation of the long axis typifying lake depressions (Grigoriev, 1993). Nikolay Lake consists of five subbasins and is about $8 \mathrm{~km}$ wide from east to west and about $6 \mathrm{~km}$ long from north to south. Approximately $70 \%$ of the lake basin has a water depth of less than $2 \mathrm{~m}$. A maximum water depth of $30 \mathrm{~m}$ was recorded in one subbasin. Recent studies suggest that the lake is of thermokarst origin (Schwamborn et al., 2002a).

The area is characterised by an Arctic climate with long, severe winters and short summers. Present day mean July $\left(T_{\mathrm{VII}}\right)$ and mean January $\left(T_{\mathrm{I}}\right)$ temperatures are around 5 and $-30{ }^{\circ} \mathrm{C}$, respectively. The mean annual temperature $(T)$ varies between -13 and -15 ${ }^{\circ} \mathrm{C}$. Annual precipitation $(P)$ is about $200 \mathrm{~mm}$ with most falling in summer (Atlas Arktiki, 1985).

The study area is in the zone of continuous permafrost. The thickness of the permafrost reaches 500-600 m (Grigoriev et al., 1996), while the active layer is about $20-40 \mathrm{~cm}$ thick. Soils in the area are mainly tundra-gley and peaty-gley (histosols and inceptisols). The area belongs to the "northern tundra zone' (Atlas Arktiki, 1985). Moss-grass low-shrub tundra dominates the vegetation, with vascular plant species such as Betula exilis, Dryas punctata, Salix pulchra, Cassiope tetragona, Oxyria digyna, Alopecurus alpinus, Poa arctica, Carex ensifolia, C. rotundifolia and Eriophorum medium, mosses such as Aulacomnium turgidum, Hylocomium alaskanum, Drepanocladus iniciatus and Calliergon sarmentosum, and lichens such as Alectoria ochroleuca, Cetraria cuculliata and C. hiascus.

\section{Methods}

Cores were collected from the central part of one of the lake subbasins (Fig. 1). Drilling of the lake sediments was performed from 2.2-m-thick ice in the spring of 1999 using a frozen-ground rotary coring kit (Schwamborn et al., 2002a). A 325-cm-long core (A1) was recovered from $14 \mathrm{~m}$ below the ice cover. In this core, only the upper $95 \mathrm{~cm}$ unit has been interpreted as being lake sediment; the lower 230 $\mathrm{cm}$ unit has been interpreted as having the same origin as the sediments in the bluffs around the lake (Schwamborn et al., 2002a,b). Subsamples taken at $5 \mathrm{~cm}$ intervals were used to analyse the organic carbon content (TOC) of this core. A gravity corer was used to collect additional short cores adjacent to the longer core, in order to have enough material for other analyses. Material from the longest gravity core of $83 \mathrm{~cm}(\mathrm{CN} 2)$, recovered a very short distance (less than $10 \mathrm{~m}$ ) from core A1, was used for micropaleontological (pollen, rhizopod and chironomid), TOC and 
Table 1

Radiocarbon dates from Lake Nikolay

\begin{tabular}{|c|c|c|c|c|}
\hline Core & Sample depth $(\mathrm{cm})$ & Lab. no & ${ }^{14} \mathrm{C}$ yr BP & Cal. yr BP (95.4\% probability) \\
\hline $\mathrm{CN} 2$ & $1-3$ & KIA12527 & $506 \pm 36$ & $560 \pm 60$ \\
\hline $\mathrm{CN} 2$ & $9-11$ & AA40889 & $1547 \pm 49$ & $1430 \pm 110$ \\
\hline $\mathrm{CN} 2$ & $21-23$ & AA40890 & $2943 \pm 45$ & $3113 \pm 180$ \\
\hline $\mathrm{CN} 2$ & $41-43$ & KIA12528 & $4475 \pm 38$ & $5130 \pm 170$ \\
\hline $\mathrm{CN} 2$ & $57-59$ & KIA18396 & $8090 \pm 70$ & $9100 \pm 95$ \\
\hline $\mathrm{CN} 2$ & $77-79$ & KIA18397 & $8940 \pm 90$ & $10,110 \pm 180$ \\
\hline A1 & $10-15$ & KIA9113 & $2080 \pm 30$ & $2050 \pm 100$ \\
\hline A1 & $30-35$ & KIA9114 & $4335 \pm 40$ & $4931 \pm 100$ \\
\hline A1 & $55-60$ & AA40887 & $6975 \pm 53$ & $7800 \pm 130$ \\
\hline A1 & $65-70$ & AA40888 & $7777 \pm 90$ & $8680 \pm 300$ \\
\hline A1 & $90-95$ & KIA9115 ${ }^{\mathrm{a}}$ & $6330 \pm 101$ & $7210 \pm 220$ \\
\hline A1 & $90-95$ & KIA12529a & $7090 \pm 40$ & $7880 \pm 90$ \\
\hline A1 & $95-100$ & KIA9116 & $12,480 \pm 60$ & $14,900 \pm 700$ \\
\hline
\end{tabular}

Radiocarbon ages $\left({ }^{14} \mathrm{C}\right.$ yr BP) are calibrated into calendar years (cal. yr BP) following Stuiver et al. (1998).

"Ages assumed to be "too young".

$\delta^{13} \mathrm{C}_{\text {org. }}$ analyses. Each subsample is $2 \mathrm{~cm}$ in length. Samples for radiocarbon dating were taken from both cores. Selected plant remains were AMS radiocarbon

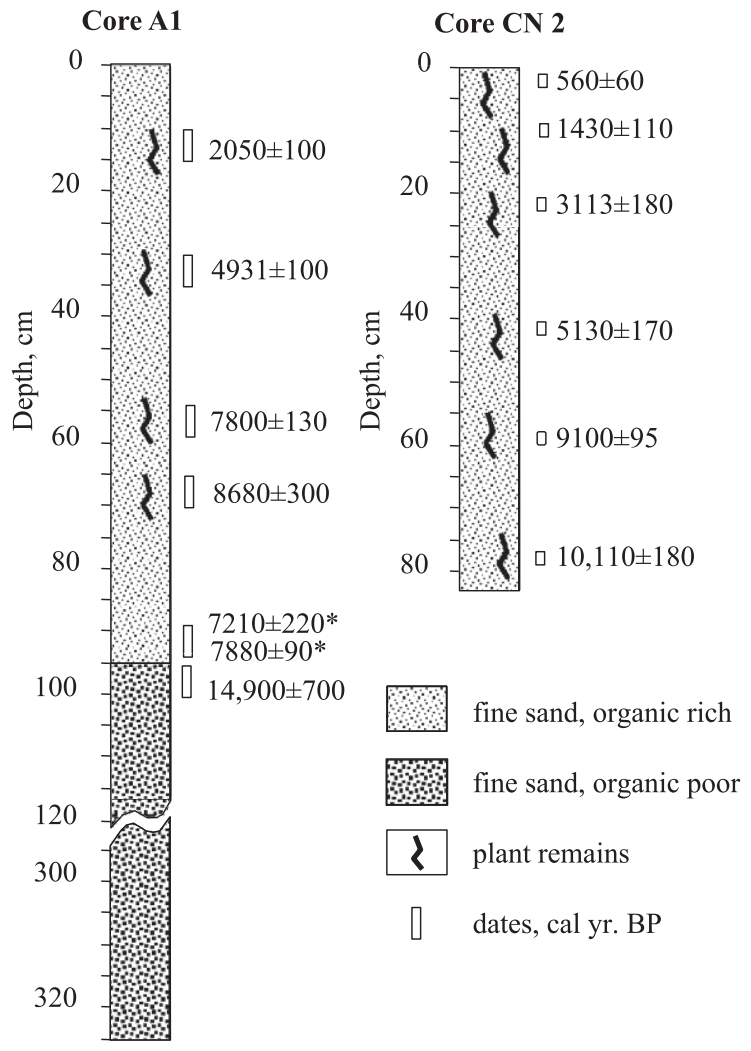

Fig. 2. Lithology and cal. ages for cores $\mathrm{A} 1$ and $\mathrm{CN} 2$. dated at the Leibniz Laboratory, Kiel and the AMS Laboratory of the Arizona University. A total of 13 samples were dated from cores A1 and CN2 (Table 1 and Fig. 2).

The sandy peat profile, Barbarina Tumsa $\left(73^{\circ} 34^{\prime} \mathrm{N}\right.$, $123^{\circ} 21^{\prime} \mathrm{E}$ ), is situated ca. $30 \mathrm{~km}$ from the lake (Fig. 1). Samples for pollen analyses were collected from the cleaned section in $10 \mathrm{~cm}$ intervals during field work in 2001. A total of four samples were dated from the profile (Table 2).

Total organic carbon (TOC) was analysed using a Metalyt-CS-1000-S (Eltra) in homogenised samples after removal of carbonate with $10 \% \mathrm{HCl}$ at a temperature of $80{ }^{\circ} \mathrm{C}$. The analyses were accurate to $\pm 5 \%$ for TOC contents $>1$ wt. $\%$ (wt: weight) and $\pm 10 \%$ for TOC contents $<1$ wt. $\%$.

A stable carbon isotope profile was determined for the TOC contents from core A1. $\delta^{13} \mathrm{C}_{\text {org. }}$ contents were measured using a FINNIGAN DELTA $\mathrm{S}$ mass

Table 2

Radiocarbon dates from Barbarina Tumsa section

\begin{tabular}{llll}
\hline $\begin{array}{l}\text { Sample } \\
\text { depth }(\mathrm{cm})\end{array}$ & Lab. no & ${ }^{14} \mathrm{C}$ yr BP & $\begin{array}{l}\text { Cal. yr BP } \\
(95.4 \% \text { probability })\end{array}$ \\
\hline $80-90$ & KIA18401 & $1795 \pm 35$ & $1805 \pm 65$ \\
$150-160$ & KIA18400 & $3180 \pm 30$ & $3460 \pm 50$ \\
$190-200$ & KIA18399 & $3800 \pm 30$ & $4280 \pm 140$ \\
$230-240$ & KIA18398 & $6280 \pm 40$ & $7290 \pm 60$ \\
\hline
\end{tabular}

Radiocarbon ages $\left({ }^{14} \mathrm{C}\right.$ yr BP) are calibrated into calendar years (cal. yr BP) following Stuiver et al. (1998). 


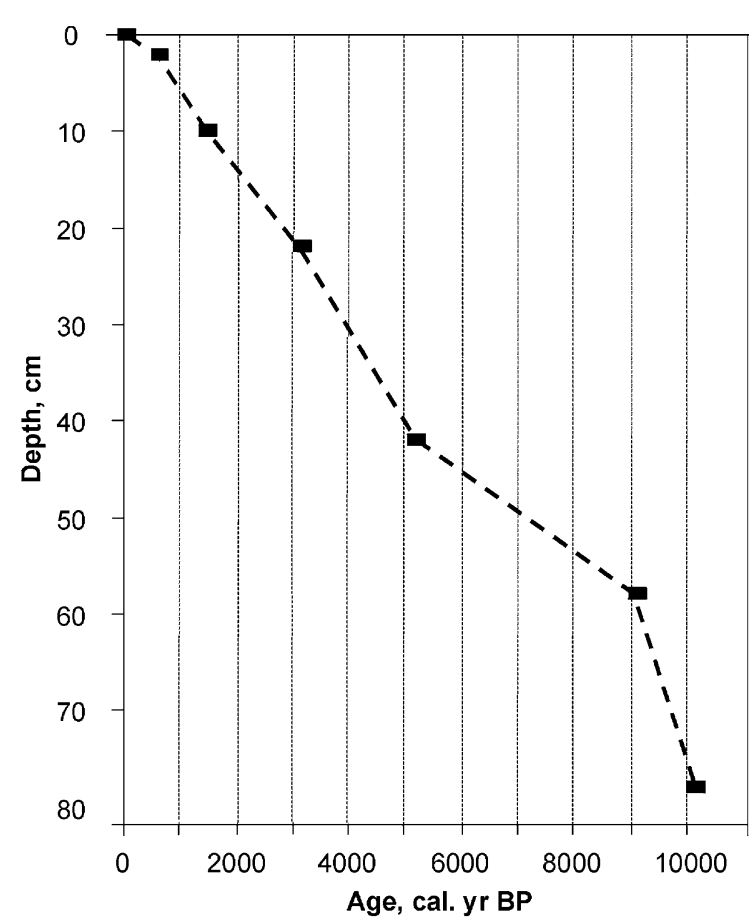

Fig. 3. Age/depth model.

spectrometer after removal of carbonate with $10 \%$ $\mathrm{HCl}$ in Ag-cups and combustion to $\mathrm{CO}_{2}$ in a Heraeus elemental analyser (Fry et al., 1992). Accuracy of the methods was determined by parallel analysis of international standard reference material. The analyses were accurate to $\pm 0.2 \%$ o.

The core CN2 sediments were analysed for testate amoebae, pollen and chironomids. For rhizopod analyses, dry samples weighing $5 \mathrm{~g}$ were placed in $50 \mathrm{ml}$ of water. Large organic and mineral particles were removed with a $500 \mu \mathrm{m}$ sieve. A drop of suspension $(0.05 \mathrm{ml})$ was placed on a slide and glycerol was added. On average, five subsamples per level were examined at $\times 200-400$ magnification using a light microscope. The density of rhizopod shells was calculated according to the method used in soil studies (Geltzer et al., 1985).

For chironomid analysis, wet samples were sorted in a Bogorov counting tray under a dissecting microscope $(\times 25$ magnification). To better preserve fragile parts (especially mandible and labrum) of the chironomid head capsules, the sediments were not sieved or treated with $\mathrm{KOH}$ (Walker, 2001). Chironomid head capsules were removed and mounted onto microscope slides in glycerol for taxonomic identification. Whole head capsules, and fragments containing more than half of the mentum, were counted as one head capsule. Split fragments of head capsules that included half the mentum were counted as one-half. Identifications were based on descriptions provided by Wiederholm (1983), as well as on several other publications (Pankratova, 1970; Hofmann, 1971; Sæther, 1975; Cranston, 1982; Sæther and Wang, 1996; Schnell, 1998; Makarchenko and Makarchenko, 1999). Generally, the total number of counted head capsules in each sample reached 100. The relationship between the profundal chironomid taxa and trophic conditions was reconstructed using the lake typology established by Sæther (1979). The Shannon-Weaver index $\left(H^{\prime}\right)$ was used to calculate species diversity in the chironomid spectra, following Southwood (1971). All taxa, even rare species, were included in the analysis. To interpret the chironomid record in terms of $T_{\mathrm{VII}}$, we used the estimated temperature optima $\left(T_{\mathrm{VII}-\text { opt }}\right)$ for chironomid taxa from Gaussian logit regression models based on a modern calibration set of 100 lakes located in a subarctic region of Sweden (Larocque et al., 2001).

A standard HF technique was used for pollen preparation (Berglund and Ralska-Jasiewiczowa, 1986). The relative frequency of arboreal and nonarboreal pollen taxa was calculated based on the sum of terrestrial pollen taxa. At least 200 pollen grains were counted in every sample. Calculation of spore percentages was based on a sum of pollen and spores. The relative abundances of reworked taxa (Tertiary spores and redeposited Quaternary pollen) were based on a sum of pollen and redeposited taxa, and the percentage of algae was based on a sum of pollen and algae (Berglund and Ralska-Jasiewiczowa, 1986). Tilia/TiliaGraph software (Grimm, 1991) was used for the calculation of chironomid, rhizopod, pollen and spore percentages, and for drawing diagrams (Figs. 5-8).

Two statistical approaches were used to reconstruct climate from the pollen record: the IS and standard BMA methods. Details of the IS method are described in Klimanov (1976, 1984). Reconstruction of past climate was based on the established relationships (transfer function) between percentages of tree and shrub taxa calculated for more than 800 surface pollen 
spectra from the former USSR, and modern climate variables ( $T_{\mathrm{VII}}, T_{\mathrm{I}}, T$ and $P$ ) at the sampling sites derived from the Climatic Atlas of the USSR (Klimaticheskiy Atlas SSSR, 1960). The ratio between arboreal and nonarboreal pollen was also taken into account. The reliability and accuracy of the method, determined by testing with modern pollen spectra, (Klimanov, 1976, 1984) is very high (statistical error of $\pm 0.6{ }^{\circ} \mathrm{C}$ for $T_{\mathrm{VII}}, \pm 1.0^{\circ} \mathrm{C}$ for $T_{\mathrm{I}}$ and $\pm 25 \mathrm{~mm}$ for $P$ ). However, statistical errors in the pollen-based climate reconstructions of the Russian Arctic must be larger, due to the fact that the Arctic region was relatively poorly represented in the data set used for the method calibration.

The standard BMA method (Guiot, 1990) uses a chord distance to determine the similarity between each analysed pollen spectrum and each spectrum in the reference data set. PPPBase software (Guiot and
Goeury, 1996) was used to perform all calculations and allowed us to choose the most suitable number of best analogues and to exclude "bad" analogues from the calculation. In the present study, the BMA approach was used with the modern pollen data set, which includes 1106 surface pollen spectra from northern Eurasia. These data mainly came from the compilation of Tarasov et al. (1998). However, for the present study, we compiled more than 200 additional spectra from the Russian Arctic (Bolikhovskaya and Bolikhovskii, 1994; Edwards et al., 2000; Lozhkin et al., 2001; Pisaric et al., 2001a; Solovieva, personal communication). A total of 77 arboreal and nonarboreal pollen taxa were included in the analysis. Modern climate variables at the pollen sampling sites were calculated from the updated version of the Leemans and Cramer (1991) climate database (Cramer, personal communication).
Core A1

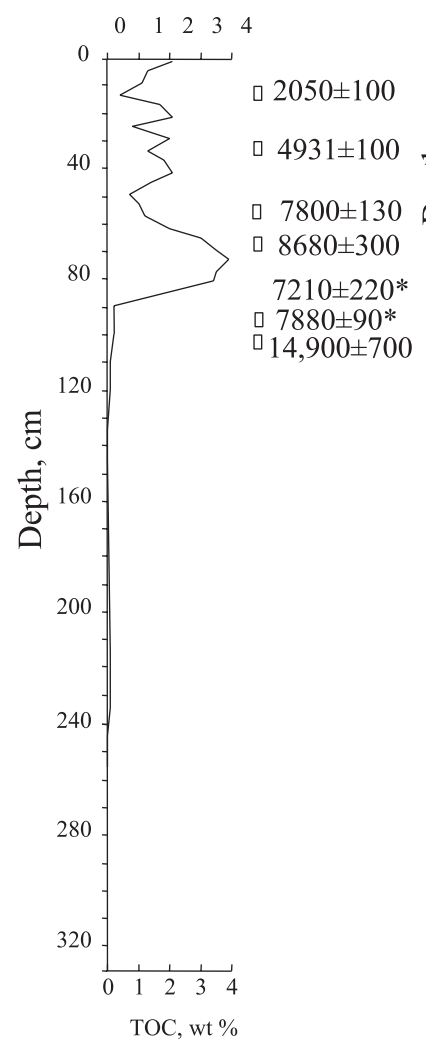

\section{Core CN2}

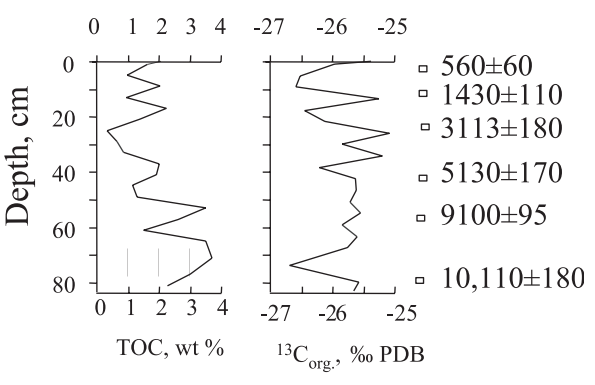

Fig. 4. Total organic carbon (TOC) and organic carbon isotopes from cores A1 and CN2. 


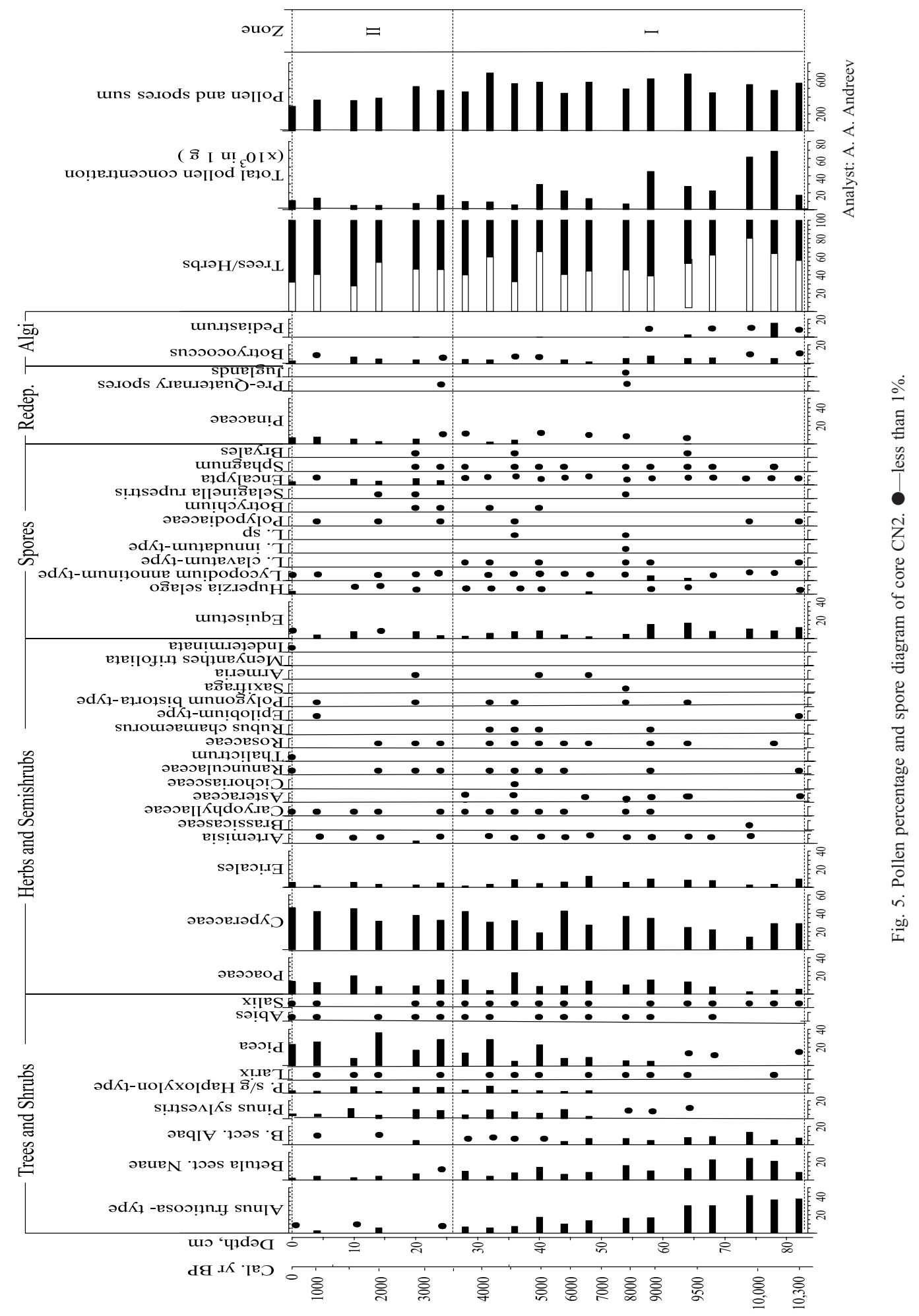




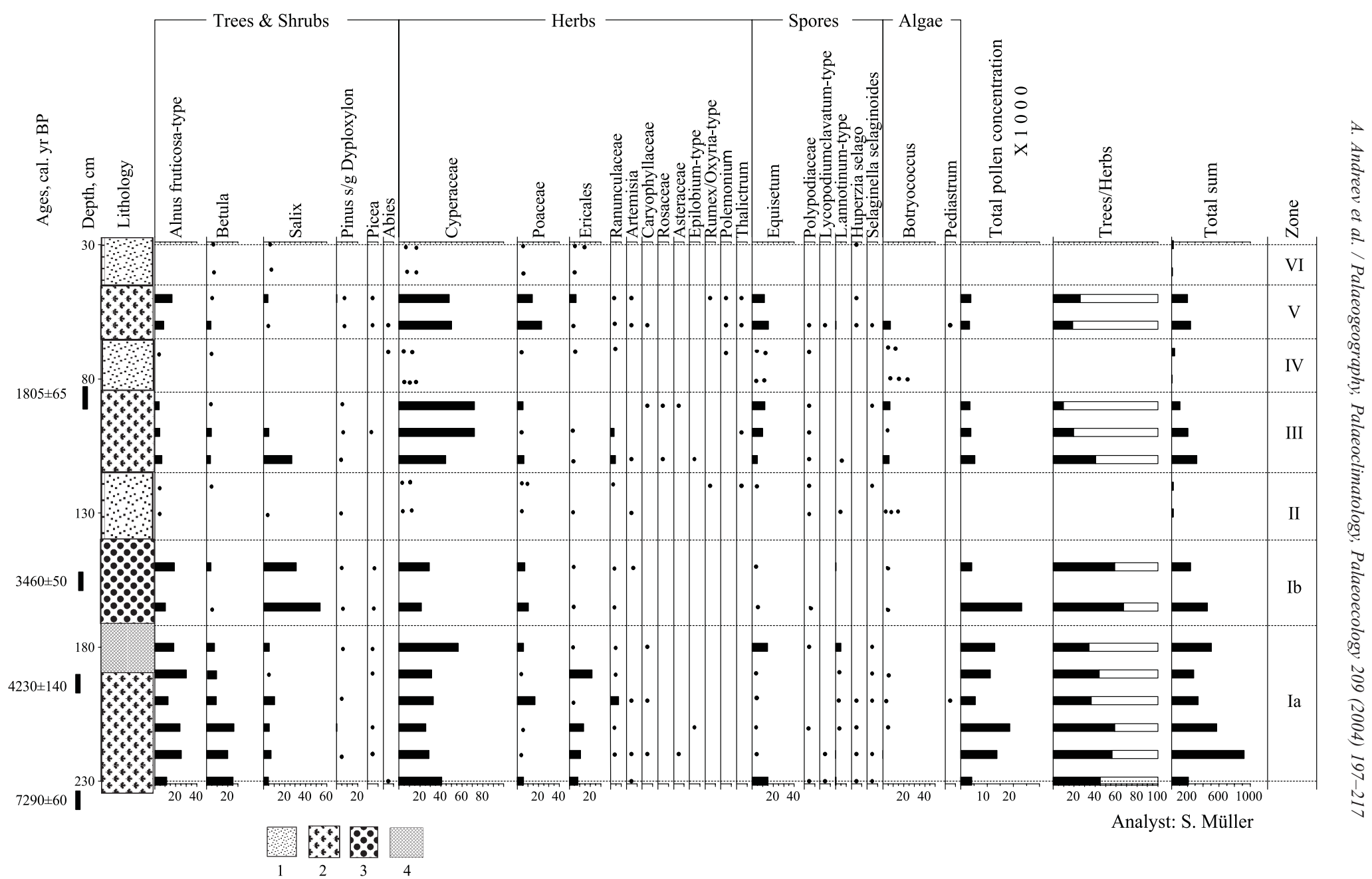

Fig. 6. Pollen percentage and spore diagram of the Barbarina Tumsa section. —-less than 1\%; 1—sand; 2—sandy peat; 3—slightly decomposed peat; 4 -sand with peat lenses. 


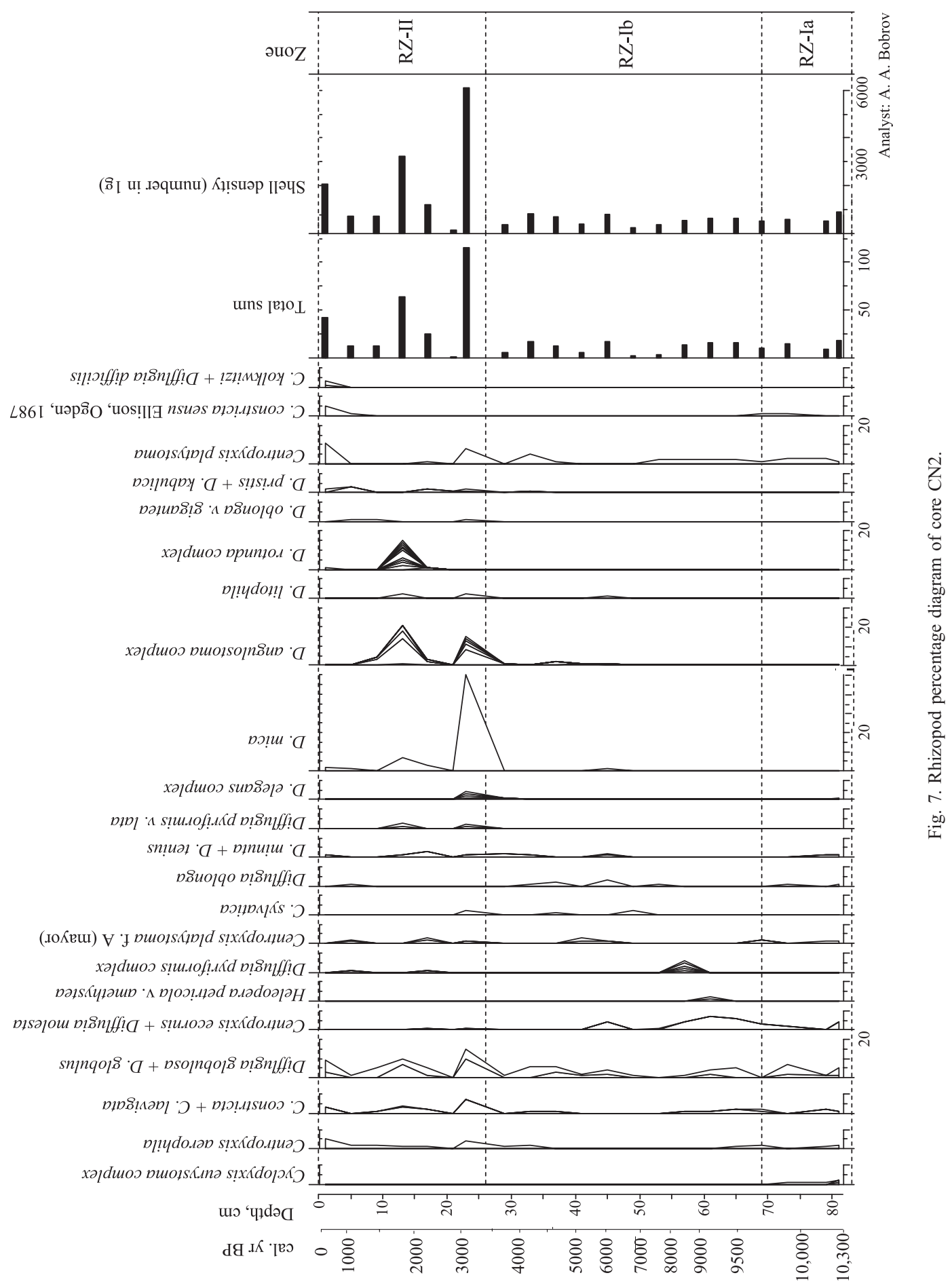


Chironomids were used to reconstruct $T_{\mathrm{VII}}$ by weighted averaging partial least squares (WA-PLS) regression (ter Braak and Juggins, 1993) based on the Swedish calibration data set (Larocque et al., 2001). The $T_{\mathrm{VII}}$ range in the data set is $7.0-14.7^{\circ} \mathrm{C}$. The best prediction model was obtained using a two-component WA-PLS regression that yielded a root mean square error of prediction (RMSEP, based on jack-knifing) of $1.13{ }^{\circ} \mathrm{C}$, a coefficient of determination $\left(r^{2}\right)$ of 0.65 and a maximum bias of $2.1{ }^{\circ} \mathrm{C}$ between measured and predicted $T_{\mathrm{VII}}$ values (Larocque et al., 2001). The $T_{\mathrm{VII}}$ reconstructions from the fossil chironomid assemblages were performed using the program WA-PLS 1.51 (Juggins and ter Braak, unpublished). To stabilise variances among taxa, percentage data were transformed using the natural logarithm $(\ln [x+1])$ prior to reconstructions. Sample-specific prediction errors were estimated by Monte Carlo simulation (500 simulations; Birks, 1995). A locally weighted regression smoothing (LOESS; Cleveland et al., 1993) with a span of 0.25 was used to help highlight the major trend in the reconstructed values.

\section{Results and interpretation}

\subsection{Lithostratigraphy}

The A1 core $(325 \mathrm{~cm})$ can be divided into two sedimentary units (Fig. 2) based on the field description and TOC measurements. The upper $95 \mathrm{~cm}$ consists of organic-rich fine sand, lake sediments with rare plant macrofossil fragments. The lower $230 \mathrm{~cm}$ consists of organic-poor fine sand deposited in nonlacustrine conditions (Schwamborn et al., 2002b). Grain size data suggest only a small influx of material from the lake catchment but a significant aeolian drifted fraction within the lake sediments (Schwamborn et al., 2002a). Core CN2 $(83 \mathrm{~cm})$ consists of organic-rich fine sand with rare plant macrofossil fragments and is similar to the upper unit of core A1 (Fig. 2).

The lower $240-190 \mathrm{~cm}$ of the Barbarina Tumsa section (Fig. 6) is sandy peat, overlaid by $20 \mathrm{~cm}$ of sand with peat lenses. From $170-140 \mathrm{~cm}$ is slightly decomposed peat. From $140-115 \mathrm{~cm}$ and $85-65 \mathrm{~cm}$ are sand with rare plant remains, overlaid by ca. $30 \mathrm{~cm}$ and ca. $20-25 \mathrm{~cm}$ of sandy peat, respectively. The uppermost $40-50 \mathrm{~cm}$ is sand.

\subsection{Chronology}

A total of 13 ages (six from $\mathrm{CN} 2$ and seven from A1) were obtained from the analysed cores (Table 1). The oldest date, $14,900 \pm 700$ cal. yr BP (Table 1) indicates the age of sand underlying the lacustrine sediments in Nikolay Lake. The sands forming the second fluvial terrace in the Lena River Delta are also IR-OSL dated between 14,500 and 10,900 yr BP (Schwamborn et al., 2002b).

The six AMS ages of handpicked plant fragments from core $\mathrm{CN} 2$ provide a reliable depth/time relation (Fig. 3), which has been used for the chronology. The four AMS ages of handpicked plant fragments from the upper $70 \mathrm{~cm}$ of core A1 provide a consistent depth/time relation similar to core CN2. However, two dates from $90-95 \mathrm{~cm}$ of core A1 show younger ages (7880 \pm 90 and $7210 \pm 220$ cal. yr BP). These dates are assumed to be unreliable due to possible contamination of the sediments by younger organic material during the coring.

We assume that the lacustrine sedimentation started about 10,300 cal. yr BP. A rather high sedimentation rate (ca. $25 \mathrm{~cm} / 1000 \mathrm{yr}$ ) in the first $1000 \mathrm{yr}$ after lake formation was probably due to continuous shore abrasion during that time. The sedimentation rate decreased to ca. $4 \mathrm{~cm} / 1000 \mathrm{yr}$ between ca. 9000 and 5000 cal. yr BP. After 5000 cal. yr BP, the sedimentation rate reached ca. $7 \mathrm{~cm} / 1000 \mathrm{yr}$.

All dates from the Barbarina Tumsa section (Table 2) are in good agreement and indicate that peat accumulation started about 7300 cal. yr BP. However, because peat accumulation in this section was repeatedly interrupted by sand accumulation, we are prevented from using this record for quantitative environmental reconstruction.

\subsection{Organic carbon record}

The total organic carbon (TOC) and isotope $\left(\delta^{13} \mathrm{C}_{\text {org. }}\right)$ records were obtained from bulk organic material from cores A1 and CN2. The upper $95 \mathrm{~cm}$ of core A1 (Fig. 4) consists of lake sediments with relatively high TOC content (3.9 wt.\%) and the lower $230 \mathrm{~cm}$ consists of organic-poor nonlacustrine sediments (TOC $<0.3$ wt.\%). Relatively organic-rich sediments of core $\mathrm{CN} 2$ have a narrow range of 


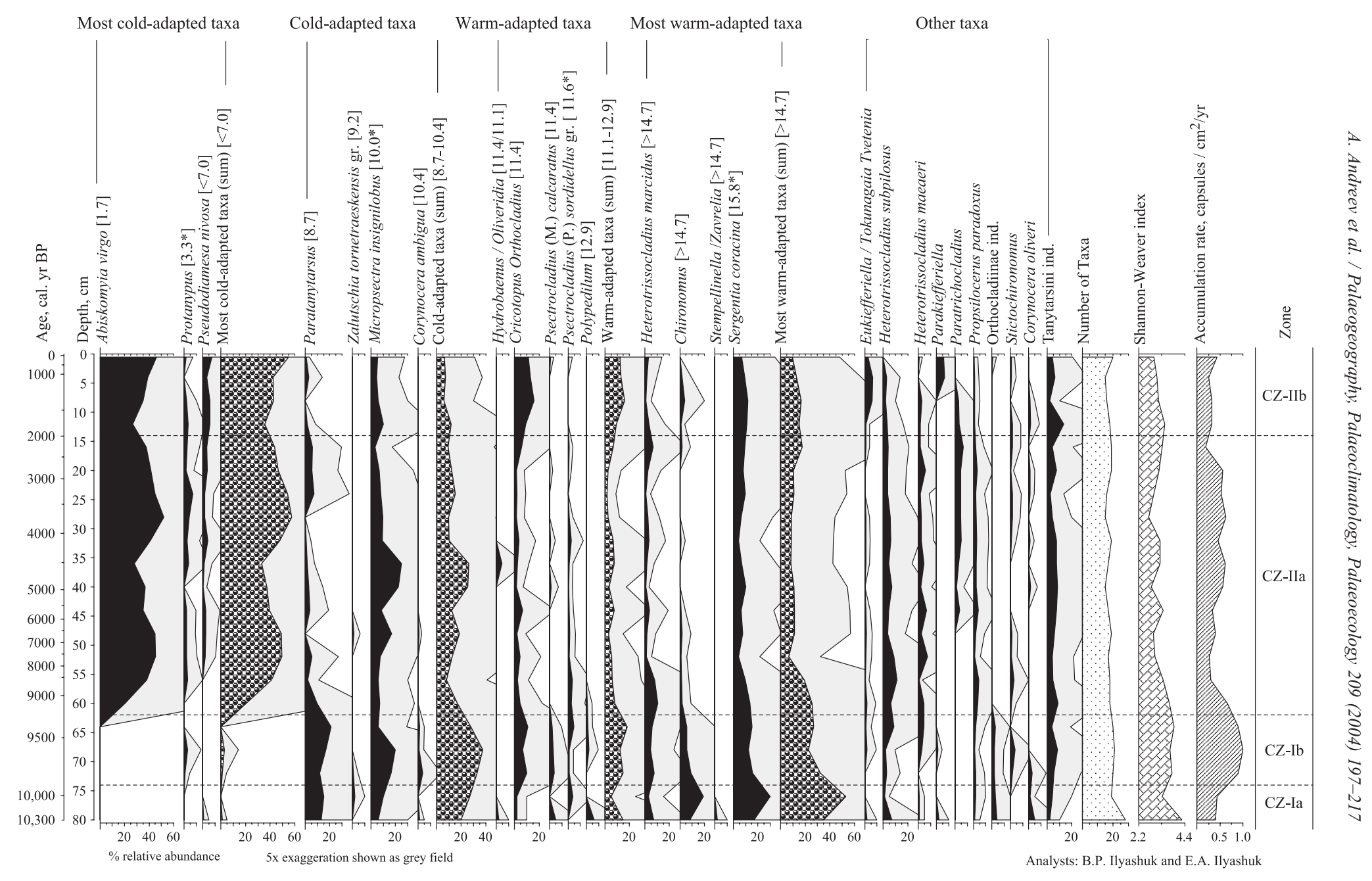

Fig. 8. Chironomid diagram of core $\mathrm{CN} 2$. Mean July air temperature optima $\left(T_{\mathrm{VII}-o p t}\right)$ for taxa are indicated in square brackets. ${ }^{*}-$ taxa having no significant relationship with $T_{\mathrm{VII}}$, according to the models described by Larocque et al. (2001). 
$\delta^{13} \mathrm{C}_{\text {org. }}$ values, between $-25 \%$ and $-27 \%$ PDB (Fig. 4). This is similar to $\delta^{13} \mathrm{C}_{\text {org. }}$. values from terrestrial plant material ( $-26.6 \%$ to $-24.3 \%$ o PDB) from the Arctic Siberia (Gundelwein, 1998). In contrast, fresh-water plankton generally has depleted $\delta^{13} \mathrm{C}_{\text {org }}$. values of $-30.0 \pm 3 \%$ PDB (Ariztegui and McKenzie, 1995). Modern $\delta^{13} \mathrm{C}_{\text {org. }}$. values of autochthonous macrophytes (26.3\% PDB) from Lake Nikolay fall between these two ranges.

A negative correlation between TOC concentrations and the $\delta^{13} \mathrm{C}_{\text {org. }}$. values in the upper unit is seen in Fig. 4. A prominent maximum in TOC content at about 8500 cal. yr BP and a few minor TOC maxima towards the top of the section are paralleled by downward shifts in $\delta^{13} \mathrm{C}_{\text {org. }}$. These findings imply that low $\delta^{13} \mathrm{C}_{\text {org. }}$. values can be explained by an increasing contribution from plankton, and thus indicate rather high lake bioproductivity. The strong relationship between $\delta^{13} \mathrm{C}_{\text {org. }}$ and TOC values points to a lacustrine rather than terrestrial source of the organic matter. The generally rather small range of carbon isotope values suggests that the lake environment was environmentally stable after the bioproductive maximum at about 8500 cal. yr BP.

\subsection{Pollen}

The sandy deposits underlying the lake sediments and recovered in the lower sedimentary unit of core A1 $(95-325 \mathrm{~cm})$ contain very few pollen grains. We identified mostly Poaceae and Cyperaceae pollen with single grains of Artemisia and a few other taxa. The extremely low pollen concentration and poor pollen preservation in these sediments make the calculation of pollen percentages impossible. Thus, these results cannot be presented in a pollen diagram. The relatively high content of green algae colonies (Pediastrum and Botryococcus) in the sample from 95-100 cm suggests a shallow unstable water body (e.g., small pond or marsh). The pollen assemblage of this sample is richer than in the lower part of this sand unit. We identified a few pollen of Cyperaceae, Poaceae and Artemisia as well as single grains of Betula sect. Nanae, Salix, and Alnus fruticosa.

The pollen diagram for core CN2 (Fig. 5) was zoned visually. Pollen zone I (PZ-I, $83-26 \mathrm{~cm}$ ) is notable for its rather high (up to 70,000 grains $/ \mathrm{cm}^{3}$ ) pollen concentration, pointing to high pollen production by plant communities in the area and probably rather dense vegetation cover. The pollen spectra are dominated by pollen of Alnus fruticosa, Betula sect. Nanae, Poaceae and Cyperaceae, suggesting that shrubby tundra vegetation dominated the area around the lake.

There is a gradual decrease in total pollen concentration and percentages of Alnus fruticosa, Betula sect. Nanae and Betula sect. Albae pollen in the upper part of PZ-I. An increase of Picea, Pinus s/g Haploxylon-type, and $P$. sylvestris pollen reflects the increasing significance of long-distance transport. The pollen spectra mirror changes in the local vegetation and a lower productivity of the plant communities.

PZ-II $(26-0 \mathrm{~cm})$ has relatively high percentages of Picea and Pinus and relatively low (up to 12,000 grains per $\mathrm{cm}^{3}$ ) pollen concentration. CyperaceaePoaceae dominates the pollen spectra and indicates that herb tundra dominated the area around the lake. Relatively high amounts of reworked Pinaceae pollen and Encalypta (moss growing on disturbed soils) spores may reflect rather scarce vegetation cover, as well as soil disturbances.

The pollen diagram of the Barbarina Tumsa section was also zoned by visual inspection (Fig. 6). PZ-Ia $(240-175 \mathrm{~cm})$ has a relatively high (up to 20,000 grains per $\mathrm{cm}^{3}$ ) pollen concentration, pointing to a relatively high pollen production of plant communities around the site. The pollen spectra are dominated by pollen of Alnus fruticosa, Betula, Salix, Ericales, Poaceae and Cyperaceae, suggesting that shrubby tundra vegetation dominated the area. PZ-Ib (175$140 \mathrm{~cm}$ ) shows an increase in the percentage of Salix pollen, while that of Betula and Ericales is significantly decreased.

PZ-II $(140-115 \mathrm{~cm})$ is a sandy layer with only a few, poorly preserved pollen grains, making counting difficult. PZ-III $(115-85 \mathrm{~cm})$ has relatively high percentages of Salix and Cyperaceae pollen and Equisetum spores. Pollen concentration is relatively low. PZ-IV $(85-65 \mathrm{~cm})$ is similar to PZ-II. PZ-V $(65-45 \mathrm{~cm})$ has a relatively low pollen concentration with Cyperaceae, Poaceae pollen and Equisetum spores dominating. PZ-VI (the upper $45 \mathrm{~cm}$ ) is identical to PZ-II and PZ-IV. 


\subsection{Rhizopods}

Generally, the sediments contain few rhizopod shells. Those that were identified belong to 57 species, varieties and forms of testate amoebae (Appendix A). The rhizopods were grouped into assemblage zones (Fig. 7). Only two species, Centropyxis constricta and Centropyxis aerophyla, are eurybiotic; all others are hydrobiotic. Oligotrophic Centropyxis and Difflugia species dominate all the samples, reflecting the oligotrophic character of the lake environment. Changes in shell density and species diversity may indicate changes in shell preservation conditions, and/or in environmental conditions. Assuming that there were no changes in the sediment lithology, abrupt changes in rhizopod abundance and species diversity are likely to indicate environmental changes in the lake basin.

Rhizopod zone I (RZ-I, 83-26 cm) is characterised by a very low shell density. We subdivided the zone into RZ-Ia $(83-69 \mathrm{~cm})$, characterised by the presence of Cyclopyxis, Arcella and Centropyxis ecornis v. megastoma, and RZ-Ib (69-26 cm), characterised by a relatively high content of $C$. ecornis, Centropyxis sylvatica, and Difflugia species. Relatively high species diversity in the lower part $(83-57 \mathrm{~cm})$ of RZ-I may point to an environment favourable for the rhizopods. A significant decrease in shell density and low species diversity in the sediments between $57-45 \mathrm{~cm}$ may reflect climate deterioration.

RZ-II $(26-0 \mathrm{~cm})$ has a relatively high shell density and may indicate a more favourable environment for the rhizopod communities. An abrupt decrease in shell density and species diversity in the sediments between $23-17 \mathrm{~cm}$ may reflect climate deterioration, whereas an increase above $13 \mathrm{~cm}$ may reflect climate amelioration.

\subsection{Chironomids}

Chironomids are absent in the sandy unit underlying the lacustrine sediment. Single remains of Abiskomyia and Micropsectra were only found at $95-100 \mathrm{~cm}$ in core A1, suggesting the existence of shallow water in the lake depression. This suggestion is consistent with the pollen data from the same sample.
A total of 2533 chironomid head capsules were found in core $\mathrm{CN} 2$. The capsules belong to 37 taxa from five subfamilies: Orthocladiinae, Diamesinae, Prodiamesinae, Tanypodinae, Chironominae (tribes Chironomini and Tanytarsini). Ceratopogonidae remains are absent from all samples.

Chironomid diagram is zoned by visual inspection (Fig. 8). Chironomid zone I (CZ-I, 81-62 cm) has extremely low $(0-3 \%)$ numbers of strongly cold-adapted taxa with $T_{\text {VII-opt }}<7{ }^{\circ} \mathrm{C}$ and the highest abundance of strongly warm-adapted taxa with $T_{\text {VII-opt }}>14.7{ }^{\circ} \mathrm{C}$. In this zone, Abiskomyia, which has a very low $T_{\mathrm{VII}-o p t}$ of $1.7{ }^{\circ} \mathrm{C}$ (Larocque et al., 2001 ), is absent. Chironomini make up $26-52 \%$ of the specimens in all layers, while Orthocladiinae are relatively rare (18-42\%). Species richness (19-28 taxa) and assemblage diversity $\left(H^{\prime}=3.31-4.26\right)$ are high. We subdivided the zone into two subzones. CZ-Ia $(81-74 \mathrm{~cm})$ is characterised by a predominance of Chironomus and Sergentia coracina and strongly warm-adapted taxa (35-53\%), while CZ-Ib $(74-62 \mathrm{~cm})$ is characterised by a predominance of Paratanytarsus and Micropsectra insignilobus and taxa with a lower $T_{\text {VII-opt }}\left(8.7-10.4{ }^{\circ} \mathrm{C} ; 35-46 \%\right)$. The highest accumulation rate of chironomid head capsules is in the CZ-Ib subzone.

CZ-II $(62-0 \mathrm{~cm})$ has a high abundance of strongly cold-adapted taxa $(>30 \%$, with the exception of the bottom layer where these taxa make up $20 \%$ ). A. virgo dominates in all chironomid assemblages of this zone. Strongly warm-adapted taxa make up 7-26\%. Sergentia coracina, which has a wide thermal range and $T_{\text {VII-opt }}=15.8{ }^{\circ} \mathrm{C}$ (Larocque et al., 2001 ), is present at low values $(4-13 \%)$ in all layers. CZ-II is characterised by fluctuations in the relative abundance of $A$. virgo. Decreases (at 45-35 and $13-11 \mathrm{~cm}$ depth) are in phase with increases in the relative abundance of Paratanytarsus, Micropsectra insignilobus and Cricotopus/Orthocladius, which have a higher $T_{\text {VII-opt }}\left(8.7-11.4{ }^{\circ} \mathrm{C}\right)$. We subdivided the zone into two subzones. CZ-IIa $(62-14 \mathrm{~cm})$ has a relatively low abundance of Cricotopus/Orthocladius, while CZ-IIb $(14-0 \mathrm{~cm})$ has a relatively high abundance of Cricotopus/ Orthocladius and Eukiefferiella/Tokunagaia/Tvetenia. The accumulation rate of chironomid head capsules is relatively high throughout CZ-IIa and relatively low in CZ-IIb. 
According to Sæther's (1975) lake typology, chironomid assemblages from core $\mathrm{CN} 2$ point to oligotrophic conditions during the lacustrine sedimentation (Fig. 9a). However, assemblages from $77-55 \mathrm{~cm}$ indicate moderately oligotrophic conditions, while assemblages from $53-0 \mathrm{~cm}$ and from the bottom of the core indicate ultraoligotrophic conditions.

\subsection{Quantitative climate reconstructions}

\subsubsection{Pollen-based reconstructions}

In the application of the BMA method to the surface pollen spectra, the option of eight modern analogues with logarithmic transformation of taxa percentages gave the best correlation between actual and pollen-reconstructed climate for spectra from the Russian Arctic (Tarasov et al., 2002). This approach was used for the Nikolay Lake pollen record. Tarasov et al. (2002) suggested that modern values of $T_{\mathrm{VII}}$ and the annual sum of day temper- atures above a $5{ }^{\circ} \mathrm{C}$ base (sum of growing-degreedays with temperatures above $5{ }^{\circ} \mathrm{C}$; GDD5) could be derived from Arctic surface pollen spectra with reasonably high confidence $(R=0.80$ and 0.82 , respectively). However, pollen spectra from the Russian Arctic do not show a clear response to changes in $T_{\mathrm{I}}$ and the moisture index, important bioclimatic variables in the forested regions (Prentice et al., 1992). $P$ and runoff (difference between $P$ and evaporation $(E)$ calculated as in Cheddadi et al., 1997) were also reconstructed from the modern spectra with relatively high correlations $(R=0.68$ and 0.61 , respectively).

Values of GDD5 in our reference data set vary from $114-3800{ }^{\circ} \mathrm{C}$ day, $T_{\mathrm{VII}}$ from $4.7-28.6{ }^{\circ} \mathrm{C}, P$ from $180-710 \mathrm{~mm}$ and $P-E$ from $17-270 \mathrm{~mm}$. Modern climate values at the Lake Nikolay site, derived from the modern climate database (Cramer, personal communication), are $250 \mathrm{~mm}(P), 66 \mathrm{~mm}$ $(P-E), 223{ }^{\circ} \mathrm{C}$ day (GDD5) and $8.7{ }^{\circ} \mathrm{C}\left(T_{\mathrm{VII}}\right)$. The $T_{\mathrm{VII}}$ from the database is slightly higher than
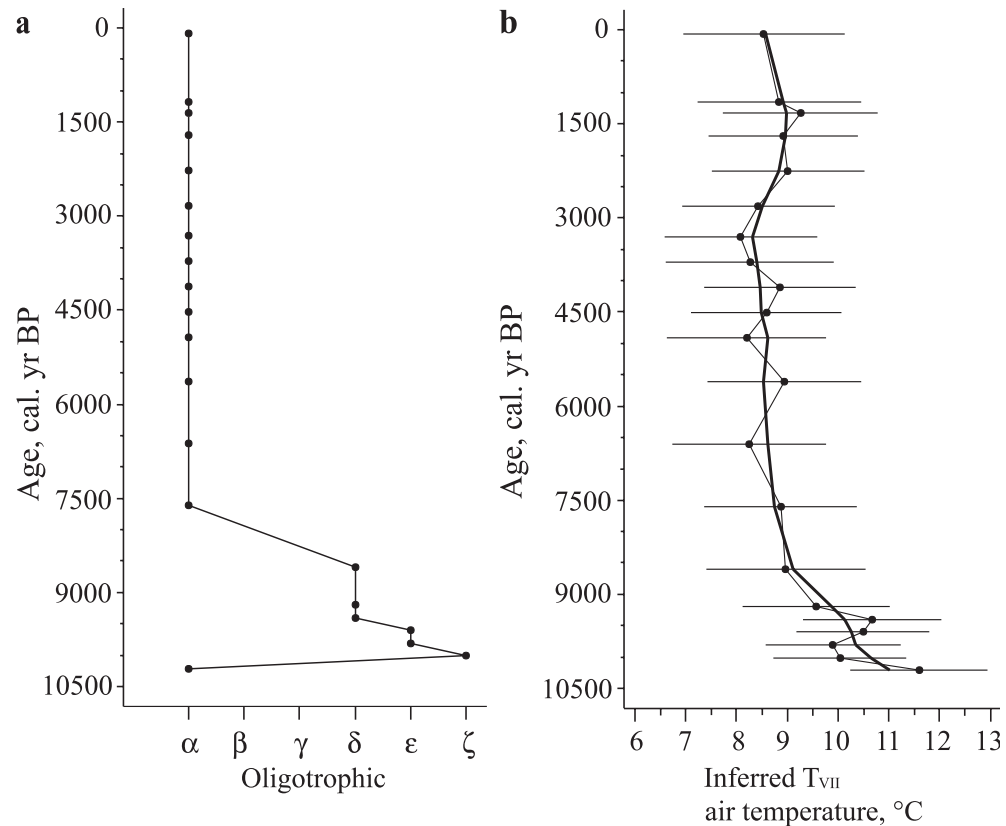

Fig. 9. (a) Trophic conditions in Nikolay Lake reconstructed from fossil chironomid assemblages. (b) Chironomid-inferred mean July air temperatures. The non smoothed temperature data (thin line), a LOESS smoother with a span of 0.25 (thick line) and the sample-specific prediction errors derived by Monte Carlo simulation (500 simulations) are shown. 


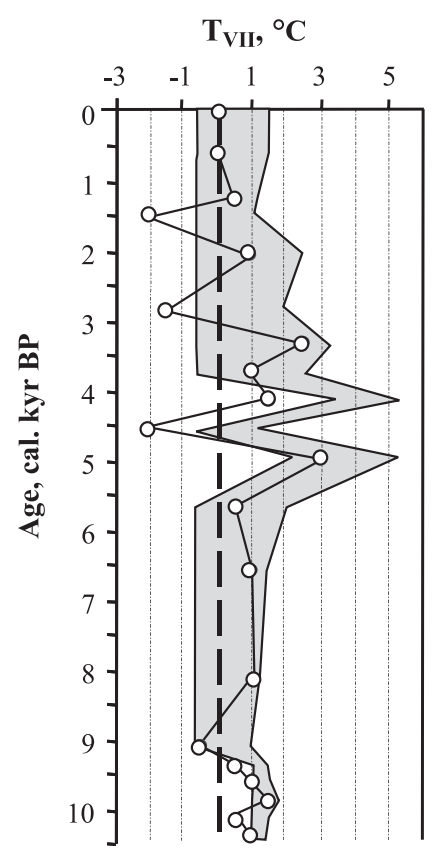

$\mathbf{P}, \mathbf{m m}$

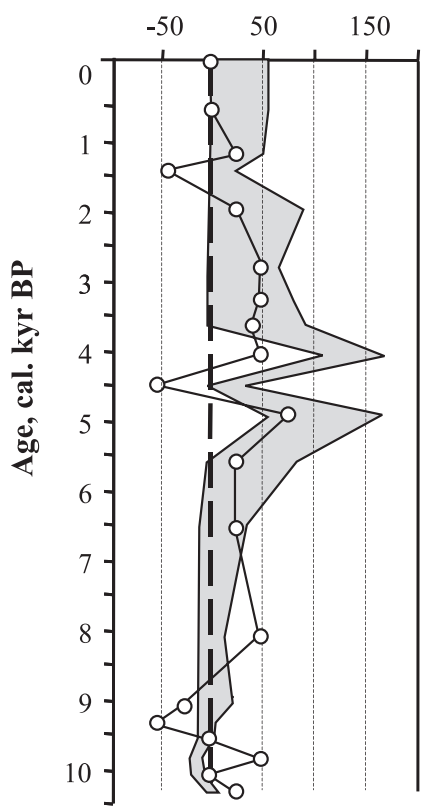

GDD5, ${ }^{\circ} \mathrm{C}$ day

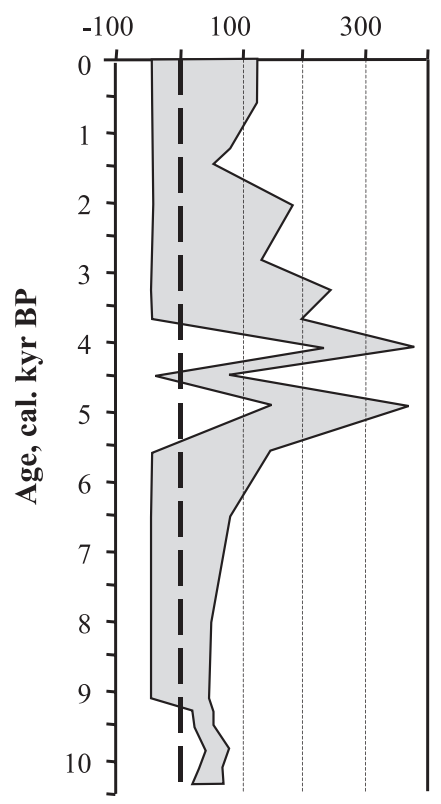

P-E, mm

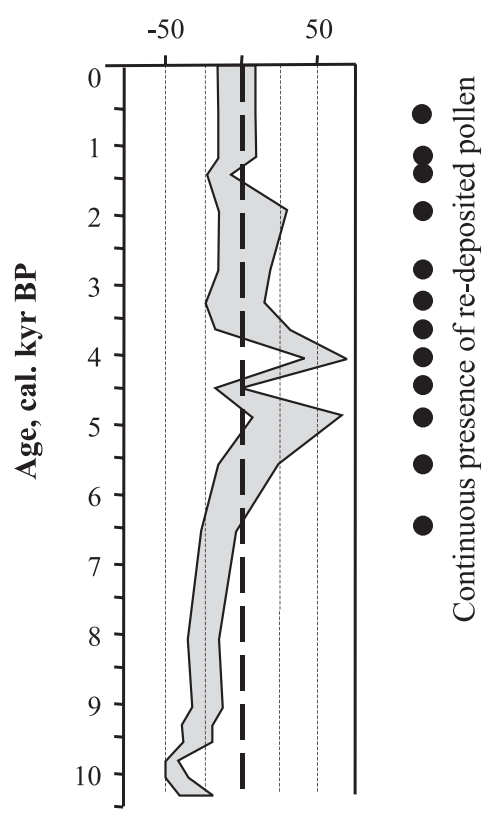

a-

Anomaly values reconstructed with the IS method

Anomaly ranges reconstructed with the BMA method

- - Line of zero anomalies

Fig. 10. Climate derived from the core CN2 pollen record by IS (Klimanov, 1984) and BMA (Guiot, 1990) methods. Anomalies are calculated as the difference between reconstructed and modern climate values from the Lake Nikolay area. 
that from the Atlas Arktiki (1985). We assume that this difference should not affect our climate reconstruction because only one source was used for the reconstruction of climate variables from modern and fossil pollen spectra. Fig. 10 shows anomalies between reconstructed and modern values from the database.

Both IS and BMA methods produce comparable results in reconstruction of thermal and hydrological changes during the last 10,300 cal. yr (Fig. 10). Negative anomalies of $T_{\mathrm{VII}}$ and $P$ reconstructed by the IS method are sometimes greater than that suggested by the BMA method. However, the differences are relatively small compared to the statistical errors of the IS reconstructions.

The reconstructions suggest that climate was relatively warm, ( $T_{\mathrm{VII}}$ up to $2{ }^{\circ} \mathrm{C}$ higher than the present day) and dry ( $P-E$ from $15-50 \mathrm{~mm}$ lower than the present day) during ca. 10,300-9200 cal. yr BP. Both reconstructions suggest a decrease in summer temperatures at about 9100 cal. yr BP. After a period of relative stability (ca. 9000-5800 cal. yr BP), climate conditions became very unstable between 5800 and 3700 cal. yr BP. A rise in summer temperatures at ca. 5000 cal. yr BP was followed by a significant decrease in temperatures at ca. 4500 cal. yr BP. Another increase in the summer temperatures is dated to ca. $4100 \mathrm{cal}$. yr BP. Hydrological parameters show similar patterns of change, with increases in precipitation and runoff at ca. 5000 and $4100 \mathrm{cal}$. yr BP, and a decrease at ca. 4500 cal. yr BP. Climate became quite stable and similar to modern-day conditions after ca. 3600 cal. yr BP. During this period, temperature and runoff values do not show significant differences from modern values. However, reconstruction by the BMA method suggests that $P$ was similar to, or slightly higher, than today.

The presence of reworked Pinaceae pollen in the record (redeposited pollen and spores are not included in the statistical analyses) might be an indicator of unstable conditions in the lake basin associated with climate changes. Reworked pollen grains are absent from the lower part of the record but are continuously present from $54 \mathrm{~cm}$ (Fig. 4). This corresponds well to the period after ca. 6500 cal. yr BP when precipitation and runoff started to rise, causing an influx of ancient pollen from the reworked shore material to the lake sediments.

\subsubsection{Quantitative $T_{V I I}$ reconstructions based on the chironomid record}

The $T_{\mathrm{VII}}$ reconstructions based on the modern calibration set from a subarctic region of northern Sweden (Larocque et al., 2001) are shown in Fig. 9b. Of the 37 chironomid taxa present in the Nikolay Lake fossil assemblages, 22 appear in the modern calibration data. The 15 fossil taxa not present in the calibration set comprise $7.6-21.6 \%$ of the fossil assemblages. However, the results obtained are interesting and comparable with pollen-based $T_{\mathrm{VII}}$ reconstructions.

The chironomid-based reconstructions suggest that the highest $T_{\mathrm{VII}}\left(9.9-11.6{ }^{\circ} \mathrm{C}\right)$ were during ca. $10,300-9200$ cal. yr BP. $T_{\mathrm{VII}}$ decreased gradually to $8.2{ }^{\circ} \mathrm{C}$ from ca. $9000-6500$ cal. yr BP. Later, during ca. $6500-3300$ cal. yr BP, $T_{\mathrm{VII}}$ were very unstable. Two short-term warm oscillations with relatively high $T_{\text {VII }}$ (up to $8.9{ }^{\circ} \mathrm{C}$ ) occurred at ca. 5600 and from 4500-4100 cal. yr BP. At ca. 3300-2300 cal. yr BP, $T_{\text {VII }}$ were about $9.0{ }^{\circ} \mathrm{C}$. Thereafter, from ca. $2300-$ 1400 cal. yr BP, they were also relatively high $T_{\mathrm{VII}}$ $\left(8.9-9.3{ }^{\circ} \mathrm{C}\right)$. The reconstructions suggest that a cooling begun after ca. 1400 cal. yr BP, when $T_{\mathrm{VII}}$ decreased to $8.5{ }^{\circ} \mathrm{C}$ (the uppermost chironomid assemblage). This chironomid-based reconstruction of $T_{\mathrm{VII}}$ is very close to the modern value $\left(8.7^{\circ} \mathrm{C}\right)$ derived from the climate database used for the surface pollen calibration.

\section{Discussion and conclusions}

Recent studies of the late Quaternary sedimentation history of the Lena Delta (Schwamborn et al., 2002a,b) suggest that sand deposits below the lacustrine sediments in Nikolay Lake are of the same origin as sands forming the second fluvial terrace in the Lena Delta. The ${ }^{14} \mathrm{C}$ and IR-OSL dates obtained from the terrace sediments on Arga Island (Schwamborn et al., 2002b) suggest that the formation of the second terrace started ca. 14,500 cal. yr BP. The $6430 \pm 120{ }^{14} \mathrm{C}$ yr BP date obtained from the outcrop of the second terrace southeast of Arga Island (Schwamborn et al., 2002b) suggests 
that terrace formation continued until the middle Holocene.

Biological remains are very rare in the late glacial sediments of core A1. The extremely low pollen concentration and poor pollen preservation are consistent with the highly energetic periglacial channel network and high accumulation rates suggested for the late glacial time in the Lena River Delta (Schwamborn et al., 2002b). However, the sample dated to 14,900 cal. yr BP (core A1) contains chironomids, spores of Pediastrum and Botryococcus, and rare pollen, indicating a shallow-water environment and sedge-grass-dwarf shrub tundra vegetation near the site. The presence of pollen and spores indicates that climate amelioration occurred during the interval corresponding to the Bölling or Allerød warming. Similar pollen spectra dated ca. 14,900 cal. yr BP are reported from the areas east (Andreev et al., 2002) and south (Pisaric et al., 2001a) of Nikolay Lake.

The lacustrine sedimentation in the lake basin is likely to have started around 10,300 cal. yr BP, according to the oldest date $10,110 \pm 180$ cal. yr BP obtained from the base of the lacustrine unit in core CN2. The pollen spectra dated to ca. 10,3008000 cal. yr BP reflect that shrub tundra with shrub alder (Alnus fruticosa) and dwarf birch (Betula nana) grew around the lake at that time. The rather high pollen concentration reflects the high productivity of plant communities, which is in agreement with the relatively high TOC content of the lake sediments (Fig. 4). The chironomid record (Fig. 8) also demonstrates a high level of species richness and diversity, suggesting that the productivity of the lake ecosystem and trophic conditions in the lake peaked at this time (Fig. 9a). The relatively high abundance of strongly warm-adapted chironomid taxa, specifically Chironomus, and the extremely low occurrence of strongly cold-adapted taxa indicate that the climate from ca. 10,300-9500 cal. yr BP was warmer than today. The rather high species diversity reflected in the rhizopod data also suggests that this interval was the warmest during the last 10,300 cal. years (Fig. 7).

Climate reconstructions (Figs. 9b, 10) imply that temperatures during ca. 10,300-9200 cal. yr BP were up to $2-3{ }^{\circ} \mathrm{C}$ warmer than the present day. Other pollen and plant macrofossil data from the area (MacDonald et al., 2000; Pisaric et al., 2001b; Andreev et al., 2002) also imply that the warmest Holocene climate occurred during that time.

The changes in the chironomid assemblages (Fig. 8), specifically the appearance and subsequent predominance of Abiskomyia, one of the best indicators of cold climate (Walker and MacDonald, 1995; Larocque et al., 2001), with its modern distribution limited to lakes north of the treeline in the lower Lena River region (Porinchu and Cwynar, 2000), reflect cooling. Such deterioration in the local climate was probably connected to a rise of sea level in the Laptev Sea region (Bauch et al., 2001), declining summer insolation and the onset of colder, more maritime summer conditions. According to the chironomid record from Nikolay Lake, this may have started after ca. 9200 cal. yr BP. Similar changes are also reflected in the chironomid record from Dolgoe Lake, where the deposition of cool-water chironomid head capsules increases dramatically at that time (Porinchu and Cwynar, 2002).

Since ca. 6000 cal. yr BP, the proportion of Alnus fruticosa and Betula nana in the local vegetation decreased and these taxa probably disappeared from the area around the lake after ca. 5000 cal. yr BP. The 7300 cal. yr old pollen record from the nearby Barbarina Tumsa peat section (Fig. 6) reflects similar trends. Alnus and Betula shrubs disappeared from the vegetation around Barbarina Tumsa ca. 200-300 yr later than the lake site. This might be due to the fact that Barbarina Tumsa is closer to the Lena River and the vegetation might therefore be better protected from the severe winter winds. In general, the Arga Island pollen records are in good agreement with pollen data from the Bykovsky Peninsula, where A. fruticosa pollen also declined about this time (Andreev et al., 2002). The youngest Larix remains found above the modern treeline (Tit-Ary Island area, south of Arga Island) are also dated to ca. 5000 cal. yr BP (MacDonald et al., 2000).

The predominance of Abiskomyia in the chironomid assemblages (Fig. 8) and the presence of another cold stenothermic taxon, Pseudodiamesa, (Brooks and Birks, 2001; Larocque et al., 2001) suggest colder conditions in the area during the last 9000 cal. yr. However, the chironomid-based temperature reconstruction points to two short, warm 
oscillations ca. 5600 and 4500-4100 cal. yr BP, consistent with pollen-based climate reconstructions (Fig. 10). This reconstruction suggests that climate conditions between ca. 5500-4000 cal. yr BP became very unstable, with a rise in summer temperatures at ca. 5500-4000 cal. yr BP and a sharp decrease in temperature ca. 4500 cal. yr BP. The chironomid-based reconstructions also suggest unstable conditions between ca. 6500-3300 cal. yr $\mathrm{BP}$, with a significant decrease in $T_{\mathrm{VII}}$ occurring at ca. 5000 cal. yr BP. It is important to note that the chironomid-based reconstructions suggest that the significant climatic changes occurred earlier than the pollen-based reconstructions indicate. This might be due to the short life cycles of chironomids and their ability to respond more rapidly than terrestrial vegetation to climatic changes (e.g., Smol et al., 1991; Battarbee, 2000).

The pollen spectra indicate that herb tundra dominated the area around the lake after 4000 cal. yr BP. The significant amount of Picea and Pinus pollen, transported over long distances, suggests a decrease in pollen productivity of the local plant communities and/or sparse vegetation cover. Relatively high amounts of redeposited Pinaceae pollen and spores of Encalypta (moss growing on disturbed soils) may also indicate sparse vegetation cover and increased erosion during that time. The Barbarina Tumsa pollen record shows very high amounts of Salix pollen in the sediments radiocarbon dated between ca. 3500-2000 cal. yr BP, which may reflect the presence of dense Salix shrubs around the site due to thicker snow cover in the river valley during winter.

Pollen-based reconstructions of hydrological parameters from the Nikolay Lake sediments show a drastic increase in precipitation and runoff at 5500 and 4200 cal. yr BP and a decrease at 4500 cal. yr BP. The climate became relatively stable and similar to modern-day conditions after ca. 4000 cal. yr BP. Temperature and runoff are not significantly different from modern values, if the confidence intervals of the reconstructions are taken into account.

The chironomid record suggests that a relatively warm period may have occurred between ca. 23001400 cal. yr BP, consistent with the slightly warmer climate reconstructed from the pollen (Fig. 10). The modern chironomid assemblage was established at ca. 1400 cal. yr BP, with a rise in the relative abundance of Abiskomyia and Cricotopus/Orthocladius species. This is also seen in the chironomid data from Dolgoye Lake, situated in the south near Tit-Ary Island, where the modern chironomid assemblage was established at ca. 1400 cal. yr BP (Porinchu and Cwynar, 2002).

Although the Nikolay pollen record does not indicate significant changes in temperature during the last 1500 years, changes in the chironomid assemblages and chironomid-based reconstruction suggest some cooling. Conversely, environmental conditions were favourable for rhizopods (or for preservation of their remains) during that interval, as indicated by the high density of rhizopod shells.

The continuous radiocarbon-dated multiproxy records from Nikolay Lake have enabled the reconstruction of environments during the last 10,300 cal. years in the western part of the Lena River Delta. Our results suggest that the local climate around the lake was warmer than the present day between 10,300-9200 cal. yr BP and was similar to the present after 3600 cal. yr BP. Biological proxies suggest that the period from 5800-3700 cal. yr BP was characterised by unstable climate conditions. However, this needs to be verified by further investigations.

\section{Acknowledgements}

The paper is based on activities supported by the German Ministry of Science within the GermanRussian cooperation framework "Laptev Sea System 2000". The research was supported by a project of the Helmholtz Association of National Research Centers (HGF) "Natural climate variations from 10,000 years to the present day". We would like to thank I. Larocque for allowing us to use the chironomid-temperature calibration data set, and S. Juggins and C.J.F. ter Braak for providing a prerelease copy of the WA-PLS program. We especially thank Paul Jasinski for polishing the English and for making critical comments on the first version of the manuscript. We also thank two anonymous reviewers for their critical but helpful comments and suggestions. 


\section{Appendix A. List of testate amoebae in the Holocene deposits of Nikolay Lake}

Taxa with similar ecological preferences were grouped into the following ecological complexes:

$\begin{array}{ll}\text { Cyclopyxis eurystoma complex } & \begin{array}{l}\text { C. eurystoma, Arcella vulgaris, } \\ \text { C. ecornis v. megastoma; }\end{array} \\ \text { Difflugia pyriformis complex } & \begin{array}{l}\text { D. pyriformis, Pontigulasia } \\ \text { compressa, P. elisa; Phryganella } \\ \text { acropodoa } \text { v. australica, } \\ \text { Centropyxis gibbosa; }\end{array} \\ \text { Centropyxis platystoma } & \text { Two forms: major and minor; } \\ \text { Difflugia elegans complex } & \text { D. elegans, Difflugia ampla } \text { c.f., } \\ & \text { Centropyxis aerophila } \text { v. } \\ & \text { sphagnicola, Centropyxis sp.; } \\ \text { Difflugia angulostoma complex } & \text { D. angulostoma, Difflugia } \\ & \text { brevicola, Difflugia decloitrei, } \\ & \text { Difflugia labiosa, Difflugia } \\ & \text { litophila, Difflugia mammilaris, } \\ & \text { Centropyxis aculeata; } \\ & \text { D. rotunda, Difflugia globularis, } \\ & \text { C. platystoma } \text { v. armata, } \\ \text { Difflugia rotunda } \text { complex } & \text { C. ecornis sensu Ogden, Hedley, } \\ & \text { 1980, Difflugia } \text { sp. }\end{array}$

\section{References}

Andreev, A.A., Klimanov, V.A., 2000. Quantitative Holocene climatic reconstruction from Arctic Russia. J. Paleolimnol. 24 (1), $81-91$.

Andreev, A.A., Schirrmeister, L., Siegert, Ch., Bobrov, A.A., Demske, D., Seiffert, M., Hubberten, H.-W., 2002. Paleoenvironmental changes in northeastern Siberia during the Upper Quaternary - evidence from pollen records of the Bykovsky Peninsula. Polarforschung 70, 13-25.

Andreev, A.A., Tarasov, P.E., Klimanov, V.A., Melles, M., Lisitsina, O.M., Hubberten, H.-W., 2004. Vegetation and climate changes around the Lama Lake, Taymyr Peninsula during the late Pleistocene and Holocene reconstructed from pollen records. Quat. Int. (in press).

Andreev, A.A., Tarasov, P.E., Siegert, Ch., Ebel, T., Klimanov, V.A., Bobrov, A.A., Melles, M., Dereviagin, A.Yu., Hubberten, H.-W., 2003. Vegetation and climate changes on the northern Taymyr, Russia during the upper Pleistocene and Holocene reconstructed from pollen records. Boreas 32, 484-505.

Ariztegui, D., McKenzie, J.A., 1995. Temperature-dependent carbon-isotope fractionation of organic matter: a potential paleoclimatic indicator in Holocene lacustrine sequences. In: Frenzel, B. (Ed.), Problems of Stable Isotopes in Tree-Rings, Lake Sediments and Peat-Bogs as Climatic Evidence for the Holocene. Gustav Fischer Verlag, Stuttgart, pp. 17-28.

Atlas Arktiki, 1985. GUGK, Moscow (in Russian).
Battarbee, R.W., 2000. Palaeolimnological approaches to climate change, with special regard to the biological record. Quat. Sci. Rev. 19, 107-124.

Bauch, H.A., Mueller-Lupp, T., Taldenkova, E., Spielhagen, R.F., Kassens, H., Grootes, P.M., Thiede, J., Heinemeier, J., Petryashov, V.V., 2001. Chronology of the Holocene transgression at the north Siberian margin. Glob. Planet. Change 31 (1-4), 125-139.

Berglund, B.E., Ralska-Jasiewiczowa, M., 1986. Pollen analysis and pollen diagrams. In: Berglund, B.E. (Ed.), Handbook of Holocene Palaeoecology and Palaeohydrology. Interscience, New York, pp. 455-484.

Birks, H.J.B., 1995. Quantitative palaeoenvironmental reconstructions. In: Maddy, D., Brew, J.S. (Eds.), Statistical Modelling of Quaternary Science Data. Technical Guide 5, Quaternary Research Association, Cambridge, pp. 161-254.

Bolikhovskaya, N.S., Bolikhovskii, V.F., 1994. Landscape and climate conditions of cryogenesis during late Pleistocene on the Yamal Peninsula. VSEGINGEO. Pos. Zelenyi. Dep. VINITI N3082-B94. 40 pp. (in Russian).

Brooks, S.J., Birks, H.I.B., 2001. Chironomid-inferred air temperatures from late-glacial and Holocene sites in north-west Europe: progress and problems. Quat. Sci. Rev. 20, 1723-1741.

Cheddadi, R., Yu, G., Guiot, J., Harrison, S.P., Prentice, I.C., 1997. The climate of Europe 6000 years ago. Clim. Dyn. 13, 1-9.

Cleveland, W.S., Grosse, E., Shyu, W.M., 1993. Local regression models. In: Chambers, J.M., Hastie, T.J. (Eds.), Statistical Models. Chapman \& Hall, London, pp. 309-376.

Cranston, P.S., 1982. A key to the larvae of the British orthocladiinae (Chironomidae). Sci. Publ. Freshw. Biol. Assoc. 45, 1-152.

Edwards, M.E., Anderson, P.M., Brubaker, L.B., Ager, T.A., Andreev, A.A., Bigelow, N.H., Cwynar, L.C., Eisner, W.R., Harrison, S.P., Hu, F.-S., Jolly, D., Lozhkin, A.V., MacDonald, G.M., Mock, C.J., Ritchie, J.C., Sher, A.V., Spear, R.W., Williams, J.W., Yu, G., 2000. Pollen-based biomes for Beringia 18,000, 6,000 and $0{ }^{14} \mathrm{C}$ yr BP. J. Biogeogr. 27 (3), 521-555.

Frenzel, B., Pecsi, M., Velichko, A.A., 1992. Atlas of Paleoclimates and Paleoenvironments Reconstruction of Northern Hemisphere. Gustav Fischer Verlag, Stuttgart.

Fry, B., Brand, W., Mersch, F.J., Tholke, K., Garritt, R., 1992. Automated analysis system for coupled $\delta^{13} \mathrm{C}$ and $\delta^{15} \mathrm{~N}$ measurements. Anal. Chem. 64, 288-291.

Geltzer, Yu.G., Korganova, G.A., Alekseev, D.A., 1985. Soil Testate Amoebae and the Methods of their Investigation (Pochvennye Rakovinnye Ameby i Metody ikh Izucheniya). Moscow Univ. Press, Moscow. 78 pp. (in Russian).

Grigoriev, M.N., 1993. Cryomorphogenesis of the Lena River Mouth Area. SB RAS, Yakutsk. 176 pp. (in Russian).

Grigoriev, M.N., Imaev, V.S., Koz'min, B.M., Kunitski, V.V., Larionov, A.G., Mikulenko, K.I., Skryabin, R.M., Timirshin, K.V., 1996. Geology, Seismicity and Cryogenic Processes of the Arctic Areas of Western Yakutia. Yakutsk Scientific Center of Siberian Branch Russian Academy of Sciences, Yakutsk. 84 pp. (in Russian).

Grimm, E., 1991. TILIA and TILIAGRAPH. Illinois State Museum, Springfield, Illinois.

Grospietsch, Th., 1953. Rhizopodenanalytische untersuchungen an mooren ostholstaeins. Arch. Hydrobiol. 47 (3), 341-452. 
Guiot, J., 1990. Methodology of palaeoclimatic reconstruction from pollen in France. Palaeogeogr. Palaeoclimatol. Palaeoecol. 80, 49-69.

Guiot, J., Goeury, C., 1996. PPPBASE, a software for statistical analysis of paleoecological and paleoclimatological data. Dendrochronologia 14, 295-300.

Gundelwein, A., 1998. Eigenschaften und Umsetzung organischer Substanz in nordsibirischen Permafrostböden. Hambg. Bodenkdl. Arb. 39 (162 pp).

Harnisch, O., 1927. Einige Daten zur rezenten und fossil testacean Rhizopoden-Fauna der Sphagnen. Arch. Hydrobiol. 18, 246-360.

Harnisch, O., 1948. Rhyzopodenanalyse der Moore. Biol. Z. 67 (11/12), 551-562.

Hofmann, W., 1971. Zur taxonomie und palökologie subfossiler chironomiden (Dipt.). Seesedimenten. Archiv für Hydrobiologie. Beihefte Ergebnisse der Limnologie, vol. 6, pp. 1-50.

Klimanov, V.A., 1976. A technique of quantitative climate reconstruction for the past. Vestnik MGU, Seria Geograf. 2, 92-98 (in Russian).

Klimanov, V.A., 1984. Paleoclimatic reconstruction based on the information statistical method. In: Velichko, A.A., Wright, H., Barnosky, K.W. (Eds.), Late Quaternary Environments of the Soviet Union. University of Minnesota, Minneapolis, pp. 297-303.

Klimaticheskiy Atlas SSSR, 1960. Gidrometeoizdat, Moscow (in Russian).

Laing, T.E., Rühland, K., Smol, J.P., 1999. Past environmental and climate changes related to treeline shifts inferred from fossil diatoms from a lake near the Lena River Delta, Siberia. Holocene 9 (5), 547-557.

Larocque, I., Hall, R.I., Grahn, E., 2001. Chironomids as indicators of climate change: a 100-lake training set from a subarctic region of northern Sweden (Lapland). J. Paleolimnol. 26, 307-322.

Leemans, R., Cramer, W., 1991. The IIASA Data Base for Monthly Values of Temperature, Precipitation and Cloudiness of Global Terrestrial Grid RR-91-18. International Institute for Applied Systems Analysis, Laxenburg.

Lozhkin, A.V., Anderson, P.M., Vartanyan, S.L., Brown, T.A., Belaya, B.V., Kotov, A.N., 2001. Late Quaternary paleoenvironments and modern pollen data from Wrangel Island (northern Chukotka). Quat. Sci. Rev. 20 (1-3), 217-233.

MacDonald, G.M., Kremenetski, C.V., Velichko, A.A., Cwynar, L.C., Riding, R.T., Goleva, A.A., Andreev, A.A., Borisova, O.K., Edwards, T.W.D., Hammarlund, D., Szeicz, J.M., Forman, S., Gataullin, V.I., 2000. Holocene treeline history and climate change across northern Eurasia. Quat. Res. 53, 302-311.

Makarchenko, E.A., Makarchenko, M.A., 1999. Chironomidae. Non-biting midges. In: Tsalolikhin, S.J. (Ed.), Key to Freshwater Invertebrates of Russia and Adjacent Lands. Volume 4-Higher Insects. Diptera. Zoological Institute RAS, St. Petersburg, pp. 210-295 and pp. 670-857. (in Russian).

Meisterfeld, R., 1977. Die horizontale und vertikale Verteilung der Testaceen (Rhizopoden Testacea) in Sphagnum. Arch. Hydrobiol. 79, 319-356.

Pankratova, V.Ya., 1970. Larvae and pupae of non-biting midges of the subfamily Orthocladiinae (Diptera, Chironomidae-Tendipe- didae) of the USSR fauna. Opredeliteli Fauny SSSR. Nauka, Leningrad, p. 102. In Russian.

Pisaric, M.F.J., MacDonald, G.M., Velichko, A.A., Cwynar, L.C., 2001a. The late glacial and postglacial vegetation history of the northwestern limits of Beringia based on pollen, stomate and tree stump evidence. Quat. Sci. Rev. 20 (1-3), 235-245.

Pisaric, M.F.J., MacDonald, G.M., Cwynar, L.C., Velichko, A.A., 2001b. Modern pollen and conifer stomates from north-central Siberian lake sediments: their use in interpreting late Quaternary fossil assemblages. Arct. Antarct. Alp. Res. 33 (1), 19-27.

Porinchu, D.F., Cwynar, L.C., 2000. The distribution of freshwater Chironomidae (Insecta: Diptera) across treeline near the lower Lena River, northeast Siberia, Russia. Arct. Antarct. Alp. Res. 32, 429-437.

Porinchu, D.F., Cwynar, L.C., 2002. Late-Quaternary history of midge communities and climate from a tundra site near the lower Lena River, northeast Siberia. J. Paleolimnol. 27, $59-69$.

Prentice, I.C., Cramer, W., Harrison, S.P., Leemans, R., Monserud, R.A., Solomon, A.M., 1992. A global biome model based on plant physiology and dominance, soil properties and climate. J. Biogeogr. 19, 117-134.

Sæther, O.A., 1975. Nearctic and palaearctic Heterotrissocladius (Diptera: Chironomidae). Bull. Fish. Res. Board Can. 193, 1-67.

Sæther, O.A., 1979. Chironomid communities as water quality indicators. Holarct. Ecol. 2, 65-74.

Sæther, O.A., Wang, X., 1996. Revision of the orthoclad genus Propsilocerus Kieffer (= Tokunagayusurika Sasa) (Diptera: Chironomidae). Entomol. Scand. 27, 441-479.

Schnell, Ø.A., 1998. Guidelines for the identification of chironomid larvae in the MOLAR project. NIVA Report 3710-97.

Schönborn, W., 1962. Die Ökologie der Testaceen im oligotrophen Seen, dargestellt am Biespiel des Grosse Stechlisees. Limnologica (Berlib) 1 (2), 111-182.

Schwamborn, G., Andreev, A.A., Tumskoy, V., Rachold, V., Grigoriev, M.N., Pavlova, E.Y., Dorozhkhina, M.V., Hubberten, H.-W., 2002a. Evolution of Lake Nikolay, Arga Island, western Lena River delta, during late Weichselian and Holocene time. Polarforschung 70, 69-82.

Schwamborn, G.V., Rachold, V., Grigoriev, V., 2002b. Late Quarternary sedimentation history of the Lena Delta. Quat. Int. 89, 119-134.

Smol, J.P., Walker, I.R., Leavit, P.R., 1991. Paleolimnology and hindcasting climatic trends. Verh.-Int. Ver. Limnol. 24, 1240-1246.

Southwood, T.R.E., 1971. Ecological Methods with Particular Reference to the Study of Insect Populations. Methuen, London.

Stuiver, M., Reimer, P.J., Bard, E., Beck, J.W., Burr, G.S., Hughen, K.A., Cromer, B., McCormic, G., van der Plicht, J., Spurk, M., 1998. INTCAL 98 radiocarbon age calibration, 24,000-0 cal BP. Radiocarbon 40, 1041-1083.

Tarasov, P.E., Webb III, T., Andreev, A.A., Afanas'eva, N.B., Berezina, N.A., Bezusko, L.G., Blyakharchuk, T.A., Bolikhovskaya, N.S., Cheddadi, R., Chernavskaya, M.M., Chernova, G.M., Dorofeyuk, N.I., Dirksen, V.G., Elina, G.A., Filimonova, L.V., Glebov, F.Z., Guiot, J., Gunova, V.S., Harrison, S.P., Jolly, D., Khomutova, V.I., Kvavadze, E.V., Osipova, I.M., Panova, N.K., Prentice, I.C., Saarse, L., Sevastyanov, D.V., Volkova, 
V.S., Zernitskaya, V.P., 1998. Present-day and mid-Holocene biomes reconstructed from pollen and plant macrofossil data from the former Soviet Union and Mongolia. J. Biogeography $25,1029-1053$.

Tarasov, P.E., Andreev, A.A., Hubberten, H.-W., 2002. Quantitative climate reconstruction based on pollen data from Russian Arctic. Abstracts of European Geophysical XXVII General Assembly, Nice, France, 21-26 April 2002.

ter Braak, C.J.F., Juggins, S., 1993. Weighted averaging partial least squares regression (WA-PLS): an improved method for reconstructing environmental variables from species assemblages. Hydrobiologia 269/270, 485-502.

Tolonen, K., 1986. Rhizopod analysis. In: Berglund, B.E. (Ed.), Handbook of Holocene Palaeoecology and Palaeohydrology. Wiley, Chichester, pp. 645-666.

Velichko, A.A., Andreev, A.A., Klimanov, V.A., 1997. The dynam- ics of climate and vegetation in the tundra and forest zone during the late glacial and Holocene. Quat. Int. 41/42, 71-96.

Walker, I.R., 2001. Midges: Chironomidae and related Diptera. In: Smol, J.P., Birks, H.J.B., Last, W.M. (Eds.), Tracking Environmental Change Using Lake Sediments. Zoological Indicators, vol. 4. Kluwer Academic Publishing, Dordrecht, pp. 43-66.

Walker, I.R., MacDonald, G.M., 1995. Distributions of Chironomidae (Insecta: Diptera) and other freshwater midges with respect to treeline, Northwest Territories, Canada. Arct. Antarct. Alp. Res. 27, 258-263.

Walker, I.R., Smol, J.P., Engstrom, D.R., Birks, H.J.B., 1991. An assessment of Chironomidae as quantitative indicators of past climatic change. Can. J. Fish Aquat. Sci. 48, 975-987.

Wiederholm, T. (Ed.), 1983. Chironomidae of the Holarctic Region. Keys and Diagnoses. Part 1: Larvae. Entomol. Scand., Suppl., vol. 19, 1-457. 